\title{
Pengaruh Kualitas Pelayanan Terhadap Kepuasan Penumpang Menggunakan Jasa Angkutan Penyeberangan PT. ASDP Indonesia Ferry (Persero) Cabang Sibolga
}

\section{Muhammad Isa, S.T., M.M}

Institut Agama Islam Negeri Padangsidimpuan misastmm@gmail.com

\section{H. Aswadi Lubis, S.E., M.Si.}

Institut Agama Islam Negeri Padangsidimpuan

\section{Marliana Caniago, S.E.}

Institut Agama Islam Negeri Padangsidimpuan

\begin{abstract}
Abstrak Penelitian ini bertujuan untuk mengetahui pengaruh kualitas pelayanan terhadap kepuasan penumpang menggunakan jasa angkutan penyeberangan PT. ASDP Indonesia Ferry (Persero) Cabang Sibolga. Penelitian ini dilakukan dilatarbelakangi pentingnya menjaga loyalitas penumpang dengan memberikan kepuasan kepada mereka melalui pelayanan yang berkualitas. Penelitian ini adalah penelitian kuantitatif dengan teknik regresi linear sederhana. Pengumpulan data menggunakan angket yang disebar kepada 69 orang responden. Pengolahan data dilakukan dengan bantuan software SPSS. Dari penelitian yang telah dilakukan disimpulkan bahwa ada pengaruh positif kualitas pelayanan terhadap kepuasan penumpang menggunakan jasa angkutan penyeberangan PT. ASDP Indonesia Ferry (Persero) Cabang Sibolga. Adapun kontribusi kualitas pelayanan terhadap kepuasan penumpang adalah sebesar 62,4\%, sedangkan sisanya $37,6 \%$ dipengaruhi oleh variabel lain yang tidak diteliti dalam penelitian ini. Persamaan regresi yang diperoleh adalah Kepuasan Penumpang $=3,514+1,176$ (Kualitas Pelayanan)
\end{abstract}

Kata Kunci Pengaruh, Kualitas Pelayanan, Kepuasan Penumpang

\begin{abstract}
This research aims to know the influence of Service Quality to Passengers Satisfaction in PT. ASDP Indonesia Ferry (Persero) Cabang Sibolga. This research is important because passengers satisfaction has significant contribution to built passengers loyalty. Service quality will influence passengers satisfaction. This is a quantitative research and use simple regression technique. This research use questionnaires with 69 passengers as samples and data processing with Software SPSS. From this research researcher know that Service Quality has positive and significant influence to Passengers Satisfaction in PT. ASDP Indonesia Ferry (Persero) Cabang Sibolga. The contribute of Service Quality to Passengers
\end{abstract}


Satisfaction is $62,4 \%$ and $37,6 \%$ explained by others variables. The regression equation is Passengers Satisfaction $=3,514+1,176$ (Service Quality).

Key words $\quad$ Effect, Service Quality, Passengers Satisfaction

\section{PENDAHULUAN}

Indonesia merupakan negara kepulauan, sehingga sarana angkutan laut memiliki peran penting untuk menghubungkan suatu daerah dengan daerah yang lain. Salah satu sarana angkutan laut yang banyak digunakan oleh masyarakat adalah Ferry. Ferry merupakan sejenis angkutan kapal laut yang dapat digunakan sebagai angkutan penumpang dan barang dengan menggunakan jalur atau trayek tertentu. Keuntungan yang ditawarkan dengan menggunakan Ferry yaitu para penumpang yang akan menyeberang ke daerah yang dibatasi oleh perairan atau laut adalah kecepatan dan kenyamanan. Kapal Ferry tidak hanya mengangkut manusia saja tetapi juga mengangkut kendaraan motor, mobil, truk dan bus. Untuk melayani masyarakat yang membutuhkan sarana angkutan laut maka PT. ASDP Indonesia Ferry (Persero) telah memiliki beberapa kantor cabang pelayanan yang tersebar di seluruh Indonesia salah satunya di kota Sibolga, Sumatera Utara.

PT. ASDP Indonesia Ferry Persero adalah Perusahaan jasa angkutan penyeberangan dan pengelola pelabuhan penyeberangan untuk penumpang, kendaraan dan barang. Fungsi utama perseroan adalah menyediakan akses transportasi publik antar pulau serta menyatukan pulau-pulau besar sekaligus menyediakan akses transportasi publik ke wilayah yang belum memiliki penyeberangan guna mempercepat pembangunan.

Kota Sibolga merupakan salah satu kota yang berada di pesisir Barat Sumatera Utara dan merupakan kota terdekat untuk menyeberang ke Pulau Nias dan pulau-pulau sekitarnya. Kepulauan Nias merupakan daerah tujuan wisata yang terdiri dari empat kabupaten dan satu kota yaitu Gunung Sitoli. Oleh karena itu ada dua perusahaan transportasi laut yang tertarik untuk mendirikan cabang perusahaan di Kota Sibolga, yaitu: PT. ASDP Indonesia Ferry (Persero) Cabang Sibolga, dan PT. Wira Jaya Lines.

Kedua perusahaan tersebut memiliki keunggulan masing-masing. Kapal Ferry yang dioperasikan PT. Wira Jaya Lines memiliki keunggulan dalam hal kapasitas dan daya tampung yang lebih besar dari pada PT. ASDP Indonesia Ferry (Persero). Kapal Ferry yang dioperasikan PT. Wira Jaya Lines memiliki muatan penumpang sebesar 700 orang penumpang dan 55 unit kendaraan. Sedangkan kapal Ferry yang dioperasikan PT. ASDP Indonesia Ferry (Persero) Cabang Sibolga memiliki kapasitas penumpang sebesar 337 penumpang.

Walaupun PT. ASDP Indonesia Ferry (Persero) Cabang Sibolga memiliki kapasitas penumpang yang lebih sedikit namun PT. ASDP Indonesia Ferry (Persero) Cabang Sibolga memiliki keunggulan dibandingkan dengan PT. Wira Jaya Lines. Keunggulan dari perusahaan tersebut adalah PT. ASDP Indonesia Ferry (Persero) Cabang Sibolga merupakan perusahaan Badan Usaha Milik Negara, dan reputasi serta 
keamanan yang diberikan PT. ASDP Indonesia Ferry (Persero) Cabang Sibolga kepada penumpangnya selama ini cukup baik.

Akan tetapi berdasarkan hasil wawancara sementara dengan beberapa orang penumpang yang pernah menggunakan jasa angkut penyeberangan, lintasan Sibolga ke Gunung Sitoli atau pulau Nias, salah satunya Bapak Mahmuddin menyatakan bahwa “ banyak pelanggan yang merasa kurang nyaman dengan pelayanan yang diberikan PT. ASDP Indonesia Ferry (Persero) Cabang Sibolga terutama pelayanan yang diberikan pada kelas ekonomi. Keluhan mereka antara lain: fasilitas yang diberikan masih kurang dari yang diharapkan masyarakat, kursi untuk tempat peristirahatan yang kurang nyaman bagi penumpang untuk beristirahat, tidak adanya AC yang diberikan pada kelas tersebut, kamar mandi yang kurang memadai, ruang tunggu yang diberikan kurang layak, sehingga pelanggan merasa kurang nyaman dengan pelayanan yang diberikan PT. Pelabuhan Indonesia untuk kelas ekonomi."

Sejalan dengan hal di atas hasil wawancara dengan Ibu Herawati, seorang penumpang Ferry warga kota Sibolga, juga menyatakan bahwa " Para pelanggan merasa kurang nyaman dengan fasilitas yang diberikan PT. ASDP Indonesia Ferry (Persero) Cabang Sibolga, pada kelas ekonomi dari fasilitas yang diberikan masih kurang dari yang diharapkan penumpang, seperti kursi untuk tempat peristirahatan yang kurang nyaman".

Ketidaknyamanan pelanggan ini harus segera diatasi dan diperbaiki. Karena jika dibiarkan maka akan merusak citra pelayanan yang diberikan perusahaan. Pada akhirnya pelanggan dikhawatirkan akan pindah ke perusahaan pesaing. Pelayanan yang diberikan PT. ASDP Indonesia Ferry (Persero) Cabang Sibolga di atas kapal penyeberangan adalah mencakup: keselamatan, keamanan, kemudahan, atau keterjangkauan, kesetaraan. selain dari penerapan standar pelayanan, masyarakat akan memilih transportasi laut yang memiliki keamanan yang baik, dan harga tiket yang terjangkau di masyarakat. Permasalahan di atas melatarbelakangi perlunya dilakukan penelitian ini.

\section{TINJAUAN PUSTAKA}

\section{Kualitas Pelayanan}

\section{A. Pengertian Kualitas Pelayanan}

Menurut Crosby seperti dikutip oleh Prihantoro (2012:3), kualitas (quality) atau mutu adalah kesesuaian terhadap persyaratan-persyaratan. Persyaratan-persyaratan perlu dispesifikasikan secara jelas sehingga semua orang tahu apa yang diharapkannya. Kualitas produk (product quality) adalah salah satu sarana positioning utama pemasar. Kualitas mempunyai dampak langsung pada kinerja produk atau jasa, oleh karena itu kualitas berhubungan erat dengan nilai dan kepuasan pelanggan. Jadi kualitas bisa didefinisikan sebagai bebas dari kerusakan, tetapi sebagian besar perusahaan yang berpusat pada pelanggan mendefinisikan kualitas berdasarkan penciptaan nilai dan kepuasan pelanggan.

Kotler dan Stanton seperti dikutip oleh M. Adam (2015:2) menyatakan bahwa jasa pada dasarnya merupakan sesuatu yang tidak berwujud, yang dapat memenuhi kebutuhan dan keinginan konsumen. Dalam memproduksi suatu jasa dapat menggunakan bantuan suatu produk fisik tetapi bisa juga tidak. Pelayanan jasa tidak mengakibatkan peralihan hak suatu barang secara fisik atau nyata. Jadi jika seseorang 
pemberi jasa memberikan jasanya pada orang lain, maka tidak ada perpindahan hak milik secara fisik.

Pelayanan yang baik adalah pelayanan yang dilakukan secara ramah tamah, adil, tepat, dan dengan etika yang baik sehingga memenuhi kebutuhan dan kepuasan bagi yang menerimanya. Jadi apabila kualitas dikelola dengan tepat, maka akan terwujud kepuasan dan loyalitas pelanggan pada perusahaan. Oleh karena itu Menurut Buchari Alma (2016:282) "Kualitas pelayanan akan mendorong terwujudnya kepuasan pelanggan dan kepuasan pelanggan merupakan salah satu faktor penentu loyalitas, bila kepuasan pelanggan terbentuk maka pertumbuhan perusahaan akan terjamin'. Selanjutnya Abdurrahman (2015:423) mengatakan bahwa untuk memenangkan persaingan, perusahaan harus mampu memberikan nilai dan kepuasan kepada pelanggan melalui penyampaian produk dan jasa berkualitas dan harga bersaing.

Semua organisasi mempunyai strategi-strategi yang ditempuh untuk masa depan, semua strategi tersebut diharapkan membawa kemajuan yang berarti pada organisasi atau perusahaan, kemajuan yang berarti itu tergambar dari keberhasilan pasar. Keberhasilan pemasaran terjadi karena mutu yang baik, respon konsumen terhadap produk juga baik. Tentunya dengan prinsip mutu tersebut, keterlibatan karyawan menjadi hal yang mutlak dan penting dan pada akhirnya tujuan dari semua itu adalah terciptanya kepuasan pelanggan.

Usaha mewujudkan pelayanan yang berkualitas tidak bisa dilepaskan dari peranan penting karyawan maupun sumber daya manusia yang dimiliki perusahaan. Setiap karyawan perlu diberikan pemahaman dan motivasi untuk selalu memberikan layanan yang terbaik bagi konsumen. Selain itu karyawan juga harus menyadari bahwa yang memberikan mereka gaji sebenarnya adalah konsumen bukan perusahaan. Perusahaan memperoleh pendapatan karena adanya konsumen yang bersedia mengkonsumsi produk dan jasa perusahaan. Oleh karena itu setiap perusahaan perlu melakukan upaya-upaya peningkatan kualitas sumber daya manusia dengan harapan semakin baik pula kualitas pelayanan yang mereka berikan kepada konsumen.

Pelayanan yang baik adalah kemampuan perusahaan dalam memberikan pelayanan yang dapat memberikan kepuasan kepada pelanggan dengan standar yang telah ditetapkan. Yang dikatakan kemampuan di dalamnya dapat dilihat dari sumber daya manusia dan sarana serta prasarana yang dimiliki. Jadi dapat disimpulkan bahwa kualitas pelayanan adalah setiap hal yang dapat menimbulkan kepuasan sepenuhnya pada setiap penumpang yang menggunakan jasa penyeberangan sesuai dengan harapan dan kebutuhan yang diinginkan oleh seorang penumpang.

\section{B. Dimensi Kualitas Pelayanan dan Dasar-dasar Pelayanan}

Ada lima pokok dimensi kualitas pelayanan menurut pakar pemasaran, Berry dan Parasuraman seperti dikutip oleh Rianto Al-Arif (2010:197), antara lain sebagai berikut:

1) Bukti langsung (tangibels) meliputi fasilitas fisik, perlengkapan, pegawai,dan sarana komunikasi

2) Kehandalan (reliability) yakni kemampuan memberikan pelayanan yang dijanjikan dengan segera dan memuaskan.

3) Daya tanggap (responsiveness), yaitu keinginan para staff untuk membantu para pelanggan dan memberikan pelayanan dengan daya tanggap. 
4) Jaminan (assurance), mencakup kemampuan, kesopanan, dan sifat dapat dipercaya yang dimiliki para staff, bebas dari bahaya, risiko atau keragu-raguan.

5) Empati, meliputi kemudahan dalam melakukan hubungan, komunikasi yang baik, dan memahami kebutuhan para pelanggan.

Pada dasarnya pelayanan terhadap konsumen tergantung dari latar belakang karyawan tersebut, baik suku bangsa, pendidikan, pengalaman, budaya, atau adat istiadat. Namun agar pelayanan menjadi berkualitas dan memiliki keseragaman, setiap karyawan perlu dibekali dengan pengetahuan yang mendalam tentang dasar-dasar pelayanan.

Dalam melayani konsumen sebaiknya seorang pemasar harus mampu memahami dan mengerti akan sifat-sifat setiap konsumennya. Hal ini disebabkan masing-masing orang memiliki sifat-sifat yang berbeda yang dipengaruhi oleh suku, agama, pendidikan, pengalaman dan lainnya. Namun secara umum setiap konsumen memiliki keinginan yang sama, yaitu ingin dipenuhi keinginan dan kebutuhannya serta selalu ingin memperoleh perhatian. Berikut ini sifat-sifat konsumen yang harus dikenal, yaitu:

1) Konsumen ingin dianggap sebagai raja

Artinya seorang raja harus dipenuhi semua keinginan dan kebutuhannya. Pelayanan yang diberikan harus seperti melayani seorang raja dalam arti masih dalam batasbatas etika dan moral dengan tidak merendahkan derajat perusahaan tersebut.

2)Mau dipenuhi keinginan dan kebutuhannya

Kedatangan konsumen ke perusahaan adalah agar kebutuhan dan keinginannya terpenuhi.

3)Tidak mau didebat dan tidak mau disinggung

Usahakan setiap pelayanan diberikan dalam suasana kekeluargaan dan rileks.

Seorang pemasar harus bersikap bijak dalam mengemukakan pendapat sehingga konsumen tidak tersinggung.

4)Konsumen ingin supaya diperhatikan

Konsumen yang datang ke perusahaan pada hakikatnya ingin memperoleh perhatian. Jangan sekali-kali menyepelekan atau membiarkan mereka, berikan perhatian secara penuh sehingga mereka benar-benar merasa diperhatikan.

5)Konsumen merupakan sumber pendapatan bagi perusahaan

Pendapatan utama sebuah perusahaan berasal dari penjualan produk dan jasanya. Oleh karena itu, jika konsumen tidak dimanfaatkan secara optimal berarti menyianyiakan sumber pendapatan perusahaan.

Selain hal tersebut di atas dalam rangka memuaskan pelanggan maka perlu juga diperhatikan etiket pelayanan. Etiket pelayanan untuk berbagai acara atau kegiatan perlu ada ketentuan yang mengaturnya. Ketentuan ini dibuat agar semua komponen yang berhubungan dengan pelayanan dapat menunjang satu sama lainnya. Artinya apabila salah satu aspek diabaikan, pelayanan dari komponen lainnya menjadi tidak berguna.

Namun etiket pelayanan ini harus dilakukan oleh semua bagian dalam perusahaan agar pelayanan yang diberikan benar-benar sempurna. Adapun ketentuan yang diatur dalam etiket secara umum ialah, sikap dan prilaku, penampilan, cara berpakaian, cara berbicara, gerak-gerik, dan cara bertanya.

Oleh karena itu, banyak perusahaan selalu ingin dianggap yang terbaik dimata konsumen karena konsumen akan menjadi pelanggan yang setia terhadap produk jasa 
yang ditawarkan. Dengan kata lain pelayanan yang baik akan mampu meningkatkan image perusahaan di mata pelanggannya dan image ini harus selalu dibangun agar citra perusahaan dapat terus meningkat.

\section{Strategi Meningkatkan Kualitas Jasa}

Meningkatkan kualitas jasa tidaklah mudah, karena banyak faktor yang perlu dipertimbangkan. Upaya tersebut juga berdampak luas yaitu terhadap organisasi secara keseluruhan. Tjiptono (2007:71) mengatakan ada berbagai faktor yang perlu mendapatkan perhatian adalah sebagai berikut:

1)Mengidentifikasi determinan utama kualitas jasa

Setiap perusahaan jasa berupaya memberikan pelayanan yang baik pada pelanggan. Untuk itu manajemen perusahaan perlu mengindentifikasi determinan utama kualitas jasa dari sudut pandang pelanggan. Oleh karena itu langkah utama yang diperlukan adalah riset kepuasan untuk mengidentifikasi determinasi jasa yang paling penting bagi pasar sasaran, namun perusahaan perlu menentukan setiap determinan sepanjang waktu, karena sangat mungkin teoritas pasar mengalami perubahan.

2)Mengolah Bukti Kualitas Jasa

Tidak jarang satu perusahaan melebih-lebihkan pesan persepsi pelanggan selama dan sesudah jasa diberikan. Hal seperti ini bisa menjadi bumerang bagi perusahaan. Makin banyak janji yang diberikan makin besar pula harapan pelanggan yang bahkan menjadi tidak realistik, yang pada gilirannya akan menambah makin sulitnya memenuhi harapan pelanggan. Untuk itu, ada satu hal yang dapat dijadikan pedoman, yaitu "jangan janjikan apa yang tidak bisa diberikan, tetapi berikan apa yang dijanjikan".

3)Mengelola bukti kualitas jasa

Hal ini bertujuan untuk memperkuat persepsi pelanggan selama dan sesudah jasa diberikan. Oleh karena jasa merupakan kinerja yang tidak dapat dilihat atau dipegang (abstrak), maka pelanggan cenderung memperhatikan fakta tangibles yang berkaitan dengan jasa sebagai bukti kualitas. Bukti-bukti kualitas jasa bisa berupa fasilitas fisik jasa, penampilan pemberian jasa, perlengkapan dan peralatan yang digunakan, laporan keuangan dan logo perusahaan, selain itu berbagai faktor seperti musik, pendingin (air conditioner), aroma, lokasi dan tata letak. Hal-hal lain yang dapat menciptakan persepsi tertentu pada perusahaan jasa, misalnya keramahan, ketenangan, kecermatan, wibawa, rasionalitas, dan kemampuan fleksibilitas.

4) Mendidik konsumen

Upaya mendidik konsumen dapat dilihat dalam beberapa bentuk sebagai berikut:

a.Mendidik pelanggan untuk melakukan sendiri jasa atau pelayanan tertentu, misalnya mengisi blanko atau formulir pendaftaran, mengangkat barang belanjaan.

b. Membantu pelanggan mengetahui kapan menggunakan suatu jasa, yaitu sebisa mungkin mendorong mereka untuk memanfaatkan jasa perusahaan pada waktu pelanggan sepi.

c.Mendidik pelanggan dalam hal memakai atau menggunakan suatu jasa.

d. Meningkatkan persepsi kualitas jasa dengan cara menjelaskan kepada pelanggan alasan-alasan yang mendasari suatu kebijakan yang mungkin bisa mengecewakan mereka.

5)Mengembangkan budaya kualitas 
Budaya kualitas merupakan sistem nilai organisasi yang menghasilkan lingkungan yang kondusif bagi penyempurnaan kualitas secara berkesinambungan. Budaya kualitas terdiri dari filosofi, keyakinan, sikap, norma, nilai, tradisi, prosedur, dan harapan meningkatkan kualitas. Adapun beberapa faktor yang dapat memperlancar dan sekaligus dapat pula menghambat pelanggan dalam memperoleh jasa yang berkualitas, antara lain sebagai berikut:

a. Karyawan, misalnya seleksi, deskripsi kerja, jalur karir.

b. Organisasi atau struktur, meliputi integritas atau kordinasi semua fungsi dan sistem pelaporan.

c. Pengukuran, yaitu evaluasi kinerja pemantauan keluhan dan kepuasan pelanggan.

d. Pendukung sistem, yaitu faktor teknis, komputer, dan database.

e. Pelayanan, meliputi nilai tambahan, rentang kualitas, standar kinerja pemuasan kebutuhan dan harapan.

f. Program, meliputi pengelolaan keluhan, peralatan, penjualan, atau promosi, dan peratan manajemen.

g. Komunikasi internal, terdiri dari prosedur dan kebijakan umpan balik.

h. Kepuasan eksternal, yaitu pendidikan pelanggan penciptaan harapan, cerita perusahaan.

\section{Kualitas Pelayanan Menurut Perspektif Islam}

Dalam Islam kita diajarkan bila ingin memberikan hasil usaha baik berupa barang atau jasa hendaknya diberikan pelayanan yang berkualitas serta dengan hati yang lemah lembut. Sebagaimana Allah berfirman dalam surah Ali-Imran ayat 159 yang berbunyi:

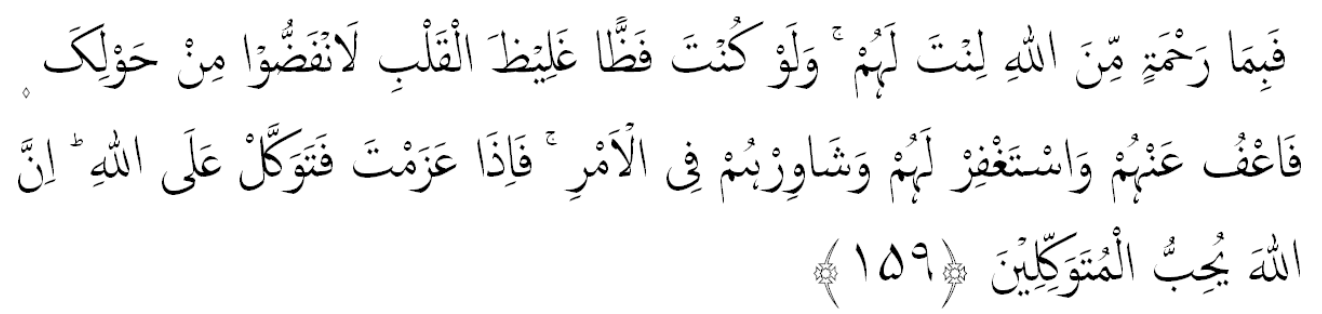

Artinya: Maka disebabkan rahmat dari Allah-lah kamu Berlaku lemah lembut terhadap mereka. Sekiranya kamu bersikap keras lagi berhati kasar, tentulah mereka menjauhkan diri dari sekelilingmu. karena itu ma'afkanlah mereka, mohonkanlah ampun bagi mereka, dan bermusyawaratlah dengan mereka dalam urusan itu. Kemudian apabila kamu telah membulatkan tekad, Maka bertawakkalah kepada Allah. Sesungguhnya Allah menyukai orang-orang yang bertawakkal kepada-Nya.

Menurut Quraish Shihab (2002:309) tafsiran ayat ini adalah Allah membimbing dan menuntun kaum muslim secara umum, pada ayat ini tuntutan diarahkan kepada Nabi Muhammad SAW sambil menyebutkan sikap lemah lembut Nabi kepada kaum muslimin khususnya mereka yang telah melakukan kesalahan dan pelanggaran dalam perang uhud. Sebenarnya cukup banyak hal dalam perang uhud yang dapat mengundang emosi manusia untuk marah, namun demikian cukup banyak pula bukti yang menunjukkan kelemah-lembutan Nabi Muhammad SAW. Beliau bermusyawarah dengan mereka sebelum memutuskan berperang, beliau menerima 
usul mayoritas mereka walau beliau sendiri kurang berkenan, beliau tidak mempersalahkan pasukan pemanah yang meninggalkan markas mereka tetapi hanya dengan halus.

Jadi berdasarkan ayat di atas, sangat jelas bahwa setiap manusia dituntut untuk berlaku lemah lembut agar orang lain merasakan nyaman bila berada di sampingnya. Apalagi seorang pelanggan sangat memiliki banyak pilihan, ketika perusahaan tidak mampu memberikan rasa nyaman dengan kelemah-lembutannya maka pelanggan akan berpindah ke perusahaan lainnya. Manajemen perusahaan haruslah menghilangkan sikap yang keras dan haruslah memiliki sifat pemaaf kepada pelanggan agar pelanggan terhindar dari rasa takut, tidak percaya, dan perasaan adanya bahaya dari pelayanan yang diterima. Dalam Al-Qur'an surat Al- Hasyr ayat 18 Allah SWT berfirman:

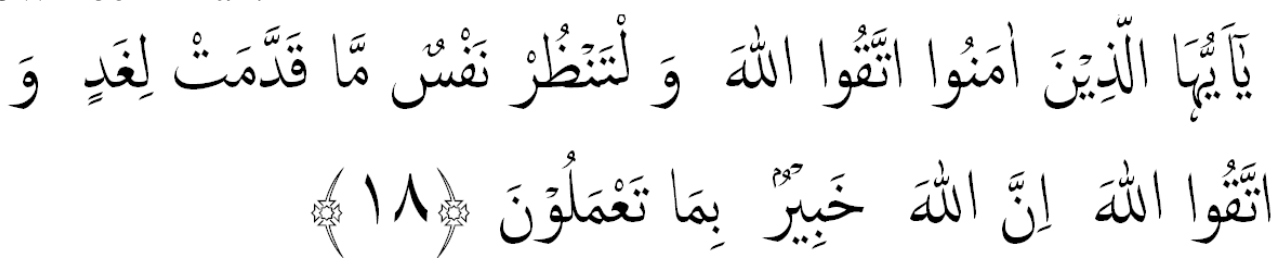

Artinya: Hai orang-orang yang beriman, bertakwalah kepada Allah dan hendaklah Setiap diri memperhatikan apa yang telah diperbuatnya untuk hari esok (akhirat) dan bertakwalah kepada Allah, Sesungguhnya Allah Maha mengetahui apa yang kamu kerjakan.

Penjelasan dari ayat di atas adalah kita harus menjadi orang yang bertakwa selain itu kita diharuskan untuk memperhatikan apa yang dikerjakan atau yang kita perbuat. Karena setiap yang diperbuat atau yang dikerjakan akan memberikan dampak untuk hari esok yaitu di akhirat nanti, jika dikaitkan dengan kualitas pelayanan dalam perusahaan jasa maka ayat ini menunjukkan bahwa sebuah perusahaan diharuskan menyusun strategi untuk menghadapi berbagai kemungkinan di masa depan dengan tetap memberikan pelayanan yang baik dan maksimal terhadap konsumen.

\section{Kepuasan}

\section{A. Pengertian Kepuasan}

Sutanto dan Khaerul Umam (2013:277) menyatakan bahwa kepuasan adalah tingkat perasaan seseorang setelah membandingkan kinerja produk atau jasa yang ia rasakan dengan harapannya. Kepuasan pelanggan merupakan evaluasi purna beli di mana alternatif yang dipilih sekurang-kurangnya memberikan hasil sama atau melampaui harapan pelanggan. Sedangkan ketidakpuasan timbul apabila hasil yang diperoleh tidak memenuhi harapan pelanggan. Kepuasan merupakan salah satu indikator keberhasilan maju atau tidaknya suatu perusahaan.

Nursalam menyebutkan kepuasan adalah perasaan senang seseorang yang berasal dari perbandingan antara kesenangan terhadap aktifitas dari suatu produk dengan harapannya. Kepuasan pelanggan berhubungan dengan mutu pelayanan yaitu dengan mengetahui tingkat kepuasan seorang pelanggan. Menurut Yazid seperti dikutip Nursalam (2012:327)ada enam faktor yang menyebabkan timbulnya rasa tidak puas pelanggan terhadap suatu produk yaitu:

1) Tidak sesuai harapan dan kenyataan

2) Layanan selama proses menikmati jasa tidak memuaskan

3) Perilaku personel kurang memuaskan 
4) Suasana dan kondisi fisik lingkungan yang tidak menunjang

5) Cost terlalu tinggi, karena jarak terlalu jauh, banyak waktu terbuang dan harga tidak sesuai

6) Promosi/ iklan tidak sesuai dengan kenyataan.

Nurzaman (2013:206) menyatakan bahwa konsumen akan membeli produk yang menawarkan "nilai terhantar pada pelanggan (customer delivered value)" yang paling tinggi. Customer delivered value adalah selisih antara nilai pelanggan total dan biaya pelanggan total. Nilai pelanggan total adalah manfaat yang diharapkan pelanggan dari barang atau jasa tertentu. Sedangkan biaya pelanggan total adalah pengeluaran yang dikeluarkan pelanggan untuk mendapatkan produk atau jasa.

Berdasarkan pengertian kepuasan yang telah dijelaskan oleh para ahli tersebut, maka peneliti dapat menyimpulkan bahwa kepuasan pelanggan merupakan suatu penilaian yang diberikan seorang pelanggan terhadap jasa yang diperolehnya dan hasilnya sesuai dengan yang diharapkannya. Perilaku pelanggan tidak dapat secara langsung dikendalikan perusahaan. Perilaku pelanggan merupakan tindakan langsung dalam mendapatkan, mengkonsumsi, serta menghabiskan produk dan jasa termasuk proses keputusan yang mendahului dan mengikuti tindakan tersebut. Untuk memberikan kepuasan kepada pelanggan, terlebih dahulu diidentifikasi jenis-jenis pelanggan itu. M.Nur Nasution (2005:102) menyatakan bahwa pada dasarnya dikenal dengan tiga jenis golongan pelanggan dalam sistem kualitas modern antara lain:

1)Pelanggan internal

Pelanggan internal adalah orang yang berada dalam perusahaan dan memiliki pengaruh pada pekerjaan atau perusahaan.

2)Pelanggan antara

Pelanggan antara adalah mereka yang bertindak atau berperan sebagai perantara, bukan sebagai pemakai akhir produk.

3)Pelanggan Eksternal

Pelanggan eksternal adalah pembeli atau pemakai akhir produk, yang sering disebut sebagai pelanggan nyata.

Harapan para pelanggan pada dasarnya sama dengan layanan seperti apakah yang seharusnya diberikan oleh perusahaan kepada pelanggan. Untuk itu dalam menciptakan kepuasan pelanggan, perusahaan harus menciptakan dan mengelola suatu sistem untuk memperoleh pelanggan yang lebih banyak.

Yuniarti (2015:240) menyatakan bahwa kesetiaan konsumen tidak terbentuk dalam waktu singkat, tetapi melalui proses belajar dan berdasarkan hasil pengalaman konsumen dari pembelian konsisten sepanjang waktu. Apabila sesuai dengan harapan, proses pembelian ini terus berulang. Hal ini dapat dikatakan bahwa telah timbul kesetiaan konsumen. Apabila dari pengalamannya konsumen tidak mendapatkan merek yang memuaskan, ia tidak akan berhenti untuk mencoba merek lain hingga ia mendapatkan produk atau jasa yang memenuhi kriteria yang mereka tetapkan.

\section{B. Ciri-ciri Konsumen yang Puas}

Kepuasan konsumen harus menjadi tujuan utama kegiatan pemasaran dalam sebuah perusahaan. Semua bagian dalam perusahaan harus berperan serta dalam menciptakan kepuasan konsumen melalui pemberian layanan yang berkualitas. Laba yang tinggi karena total penjualan yang tinggi hanya akan tercapai apabila konsumen bersedia melakukan pembelian berulang dan memperbesar kuantitas pembeliannya. 
Menurut Kotler seperti dikutip oleh Yuniarti (2015:238) menyatakan bahwa ciri-ciri konsumen yang merasa puas dengan pelayanan yang diberikan perusahaan adalah sebagai berikut:

1)Loyal terhadap produk, yaitu membeli ulang dari produsen yang sama.

2)Adanya komunikasi dari mulut ke mulut yang bersifat positif, yaitu rekomendasi kepada calon konsumen lain dan mengatakan hal-hal yang baik mengenai perusahaan dan produk perusahaan yang telah dikonsumsinya.

3)Perusahaan menjadi pertimbangan utama, yaitu ketika membeli merek lain, perusahaan yang telah memberikan kepuasan kepadanya akan menjadi pertimbangan utama.

\section{Pengukuran Kepuasan Pelanggan}

Agar kita tahu bahwa pelanggan puas atau tidak puas berhubungan dengan menggunakan jasa perusahaan, perlu adanya alat ukur untuk menentukan kepuasan konsumen. Dalam menentukan seberapa besar kepuasan konsumen dapat dilakukan dengan berbagai cara. Menurut Kotler seperti dikutip Buchari Alma (2016:288) ada empat metode untuk mengukur kepuasan pelanggan yaitu sebagai berikut:

1) Complaint and suggestion system (sistem keluhan dan saran)

Setiap organisasi yang berorientasi pada pelanggan perlu menyediakan kesempatan dan akses yang mudah dan nyaman bagi para pelanggannya guna menyampaikan saran, kritik, pendapat, dan keluhan mereka. Media yang digunakan bisa berupa kotak saran yang ditempatkan di lokasi-lokasi strategis (yang mudah dijangkau atau sering dilewati pelanggan), kartu komentar (yang bisa diisi langsung maupun dikirim via pos kepada perusahaan), saluran telepon khusus bebas pulsa, websites, dan lain-lain.

2) Ghost Shopping (pembeli bayangan)

Salah satu cara memperoleh gambaran mengenai kepuasan pelanggan adalah dengan mempekerjakan orang lain sebagai ghost shoppers untuk berpura-pura sebagai pelanggan potensial produk perusahaan dan pesaing. Mereka diminta berinteraksi dengan staff penyedia jasa dan menggunakan produk/jasa perusahaan kemudian diminta melaporkan temuannya berkenaan dengan kekuatan dan kelemahan produk/ jasa perusahaan dan pesaing.

3)Lost Customer Analysis (analisa pelanggan yang lari)

Para pelanggan yang berhenti atau telah pindah pemasok didekati agar dapat memahami mengapa hal itu terjadi sehingga dapat mengambil kebijakan perbaikan atau penyempurnaan selanjutnya. Metode ini dilakukan dengan mengidentifikasi dan mengkontak mantan pelanggan yang bersedia memberikan masukan dan evaluasi terhadap kinerja perusahaan.

4)Customer satisfaction surveys (survey kepuasan pelanggan)

Sebagian besar riset kepuasan pelanggan dilakukan dengan menggunakan metode survey baik melalui pos, telepon, email, website, maupun wawancara langsung.

\section{Jenis Kepuasan Pelanggan}

Menurut Rianto Al- Arif (2010:199) ada tiga jenis kepuasan pelanggan sebagai berikut:

1)Puas dengan produk atau jasa yaitu karena kualitasnya tinggi serta jangkauannya yang luas.

2)Puas dengan cara menjualnya: 
a. Ramah, sopan dan akrab

b. Murah senyum

c. Menyenangkan

d. Tanggap, cepat dan cermat

3)Puas dengan harganya yaitu, murah ataupun mahal sesuai dengan harapan dan dapat bersaing.

\section{E. Konsep Kepuasan Pelanggan}

Menurut Ali Hasan (2008:57) konsep teoritis kepuasan dan ketidakpuasan pelanggan dapat dikaji dari teori experien affective feelings, dan expectancy disconfirmation theory.

\section{Experien affective feelings}

Pendekatan experien affective (pengalaman= perasaan) menyatakan bahwa tingkat kepuasan pelanggan dipengaruhi perasaan positif dan negatif yang diasosiasikan pelanggan dengan barang atau jasa tertentu setelah pembelian. Dengan kata lain, selain pemahaman kognitif mengenai diskonfirmasi harapan, persamaan yang timbul dalam proses pembelian memengaruhi perasaan puas atau tidak terhadap produk yang dibeli.

\section{Expectancy disconfirmation theory}

Metode ini mendefenisikan kepuasan pelanggan menunjukkan evaluasi pengalaman yang dirasakan sama baiknya (sesuai) dengan yang diharapkan pemakaian merek lainnya dalam kelas produk yang sama, pelanggan membentuk harapan mengenai kinerja seharusnya dari merek bersangkutan. Harapan atas kinerja dibandingkan dengan kinerja aktual produk, yakni persepsi terhadap kualitas produk. Ada tiga kemungkinan yang dapat terjadi, yaitu:

Apabila kinerja > harapan maka pelanggan sangat puas

Apabila kinerja = harapan maka pelanggan puas

Apabila kinerja < harapan maka pelanggan kecewa

\section{F. Kepuasan Pelanggan dalam Perspektif Islam}

Kepuasan akan terwujud apabila terpenuhinya kebutuhan. Islam sangat mementingkan keseimbangan kebutuhan fisik yang didasarkan atas nilai-nilai syariah. Seorang muslim untuk mencapai tingkat kepuasan harus mempertimbangkan beberapa hal yaitu barang yang dikonsumsi adalah halal, baik secara zatnya maupun cara memperolehnya. Oleh karena itu kepuasan seorang muslim tidak didasarkan banyak sedikitnya barang yang dikonsumsi, tetapi didasarkan atas berapa besar nilai ibadah yang didapatkan dari produk atau jasa yang dikonsumsinya. Sebagaimana Allah SWT berfirman dalam surah Ibrahim ayat 5 yang berbunyi:

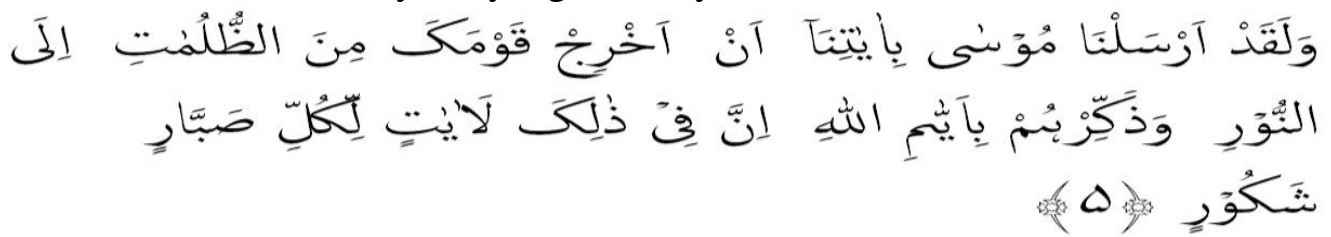

Artinya: Dan sesungguhnya Kami telah mengutus Musa dengan membawa ayat-ayat Kami, (dan Kami perintahkan kepadanya): "Keluarkanlah kaummu dari gelap gulita kepada cahaya terang benderang dan ingatkanlah mereka kepada hari- 
hari Allah". Sesunguhnya pada yang demikian itu terdapat tanda-tanda (kekuasaan Allah) bagi setiap orang penyabar dan banyak bersyukur.

Menurut Al-Maraghi (1984:224) ayat ini menunjukkan, bahwa di dalam hidup ini manusia wajib selalu berada di antara sabar dan bersyukur. Sebab di dalam hidup ini, ketika berada dalam suatu keadaan yang tidak diinginkan maka harus bersabar dan sebaliknya ketika berada dalam keadaan yang diinginkan maka harus disyukuri. Waktu dalam hidup ini adalah emas, jika kita menyia-nyiakan suatu masa dari kehidupan ini tanpa menggunakannya untuk berbakti kepada diri, agama maupun orang lain, berarti kita telah kufur dalam nikmat, menyia-nyiakan kesempatan dan tidak mengambil pelajaran dari apa yang telah menimpa umat manusia terdahulu sebelum kita. Maka hendaklah setiap orang takut menyia-nyiakan hidupnya tanpa beramal dan akan kehilangan waktu secara sia-sia yang sesudah itu akan datang azab dengan cepat.

\section{METODOLOGI PENELITIAN}

Jenis penelitian ini yang digunakan adalah penelitian kuantitatif. Sesuai dengan namanya penelitian kuantitatif adalah penelitian yang banyak di tuntut menggunakan angka, melalui dari pengumpulan data, penafsiran terhadap data tersebut. Pendekatan kuantitatif memusatkan perhatian pada gejala-gejala yang mempunyai karakteristik tertentu di dalam kehidupan manusia yang disebut variabel.

Adapun Populasi yang dipakai dalam penelitian ini adalah konsumen yang menggunakan jasa angkutan penyebarangan PT. ASDP Indonesia Ferry (Persero) Cabang Sibolga yang jumlahnya tidak dapat ditentukan (tidak dapat diketahui) karena jumlah terus bertambah.

Untuk mengetahui jumlah sampel yang digunakan dalam penelitian ini, maka digunakan rumus sampel tidak diketahui sesuai dengan pendapat Husein Umar (2013:78) berikut:

$$
n=Z^{2} P(1-P) / e^{2}
$$

Keterangan:

$\mathrm{n}=$ Ukuran sampel

$\mathrm{Z}=$ Mengacu pada tingkat kepercayaan. Dalam penelitian ini ditentukan sebesar $90 \%$ maka nilai $\mathrm{Z}$ adalah 1,65.

$\mathrm{p}=$ Variasi populasi. Variasi populasi disini dinyatakan dalam bentuk proporsi, karena tidak ada data pendahuluan mengenai populasi, variasi populasi diasumsikan heterogen (dengan proporsi 50:50). Jadi, 0,5 (1-p)=0,5x0,5=0,25

$\mathrm{e}=$ Kesalahan sampel yang ditolerir, dalam penelitian ini sebesar $10 \%$ dengan menggunakan rumus diatas, maka diperoleh perhitungan sebagai berikut:

$$
\begin{aligned}
& \mathrm{n}=\mathrm{Z}^{2} \mathrm{P}(1-\mathrm{P}) / \mathrm{e}^{2} \\
& \mathrm{n}=(1,65)^{2}(0,5)(1-0,5) /(0,1)^{2} \\
& \mathrm{n}=69
\end{aligned}
$$

Jadi sampel dalam penelitian ini adalah sebanyak 69 orang.

Instrumen penelitian ini adalah menggunakan angket sebanyak 14 butir untuk variabel kualitas pelayanan (X) dan 12 butir untuk variabel kepuasan penumpang (Y). Pernyataan angket diturunkan dari indikator-indikator variabel seperti pada tabel berikut: 


\section{Tabel 1}

Indikator Kepuasan Penumpang (Y)

\begin{tabular}{|l|c|l|c|}
\hline No & Variabel & Indikator & $\begin{array}{c}\text { No } \\
\text { Item } \\
\text { Soal }\end{array}$ \\
\hline \multirow{3}{*}{1.} & $\begin{array}{r}\text { Kepuasan } \\
\text { Penumpang }\end{array}$ & a. Pengalaman pelanggan & $1,2,3$, \\
\cline { 3 - 4 } & & 4 \\
\cline { 3 - 4 } & b. Harapan Pelanggan & 5,6, \\
\cline { 3 - 4 } & c. Menyarankan & 7,8, \\
\cline { 3 - 4 } & d. Memenuhi Kebutuhan Pelanggan & 9,10, \\
\cline { 3 - 4 } & e. Memuaskan Pelanggan & 11,12 \\
\hline \multicolumn{2}{|c}{ Jumlah } & 12 \\
\hline
\end{tabular}

Tabel 2

Indikator Kualitas Pelayanan (X)

\begin{tabular}{|l|l|l|l|}
\hline No & Variabel & Indikator & No Item Soal \\
\hline 2. & Kualitas & a. Kehandalan & $1,2,3$, \\
\cline { 3 - 4 } & Pelayanan & b. Daya Tanggap & $4,5,6$, \\
\cline { 3 - 4 } & c. Jaminan & $7,8,9,10$, \\
\cline { 3 - 4 } & d. Empati & 11,12, \\
\cline { 3 - 4 } & e. Buktinyata (Fisik) & 13,14, \\
\hline \multicolumn{2}{|c|}{ Jumlah } & 14 \\
\hline
\end{tabular}

Bentuk angket yang digunakan adalah angket tertutup yaitu responden memilih jawaban yang telah disediakan sesuai dengan keadaan dirinya. Skala yang digunakan adalah skala likert, skala likert adalah skala yang berisi lima tingkat jawaban yang merupakan skala jenis ordinal. Dimana skala likert ini merupakan cara yang paling sering digunakan dalam menentukan skor. Angket ini menggunakan skala likert yaitu sebagai berikut :

\section{Tabel 3}

Skala Likert

\begin{tabular}{|c|c|}
\hline Kategori & Bobot \\
\hline Sangat Setuju & 5 \\
\hline Setuju & 4 \\
\hline Kurang Setuju & 3 \\
\hline Tidak Setuju & 2 \\
\hline Sangat Tidak Setuju & 1 \\
\hline
\end{tabular}

\section{HASIL PENELITIAN \\ 1.Uji Instrumen}


Berdasarkan uji validitas instrumen yang telah dilakukan ternyata semua butir angket yaitu sebanyak 14 butir untuk variabel kualitas pelayanan $(X)$ valid. Sehingga tahapan uji reliabilitas dapat dilanjutkan untuk semua butir angket tersebut. Dari uji reliabilitas yang dilakukan diketahui bahwa 14 butir angket tersebut reliabel.

Selanjutnya berdasarkan uji validitas instrumen yang telah dilakukan ternyata semua butir angket yaitu sebanyak 12 butir untuk variabel kepuasan penumpang (Y) valid. Sehingga tahapan uji reliabilitas dapat dilanjutkan untuk semua butir angket tersebut. Dari uji reliabilitas yang dilakukan diketahui bahwa 12 butir angket tersebut reliabel.

\section{Uji Prasyarat}

Teknik uji normalitas yang digunakan adalah Kolmogorov-Smirnov pada taraf signifikansi 0,1 jika nilai Sig $>0,1$ maka distribusi data bersifat normal dan jika Sig $<0,1$ maka distribusi data tidak normal. Pengolahan data dilakukan dengan bantuan software SPSS, hasilnya seperti pada tabel berikut:

\section{Tabel 4}

Hasil Uji Kolmogorov Smirnov

\begin{tabular}{|ll|r|r|r|}
\hline & & \multicolumn{1}{|c|}{$\mathrm{S} 1$} & \multicolumn{1}{c|}{$\mathrm{Y}$} & $\begin{array}{r}\text { Unstandardiz } \\
\text { ed Residual }\end{array}$ \\
\hline $\mathrm{N}$ & & 69 & 69 & 69 \\
Normal & Mean & 56.97 & 45.45 & .0000000 \\
Parameters $^{\mathrm{a}, \mathrm{b}}$ & Std. & 8.273 & 5.556 & 5.07308266 \\
& Deviation & & & \\
& & .182 & .160 & .172 \\
Most Extreme & Absolute & .122 & .130 & .172 \\
Differences & Positive & -.182 & -.160 & -.170 \\
& Negative & .182 & .160 & .172 \\
Test Statistic & & $.200^{\mathrm{c}}$ & $.200^{\mathrm{c}}$ & $.200^{\mathrm{c}}$ \\
Asymp. Sig. (2-tailed) & &
\end{tabular}

a. Test distribution is Normal.

b. Calculated from data.

c. Lilliefors Significance Correction.

Dari hasil output SPSS uji normalitas di atas dapat dilihat bahwa nilai signifikan dari variabel kualitas pelayanan (X) dan varibel kepuasan penumpang (Y) adalah sebesar 0,200. Dengan demikian dapat dilihat bahwa nilai signifikan 0,200>0,1 dengan demikian dapat disimpulkan bahwa variabel kualitas pelayanan dan variabel kepuasan penumpang pada penelitian ini berdistribusi normal.

Selanjutnya dari uji linieritas yang dilakukan diperoleh tabel berikut:

\section{Tabel 5}

\section{Hasil Uji Linieritas}

ANOVA Table

\begin{tabular}{|c|c|c|c|c|c|}
\hline & $\begin{array}{l}\text { Sum of } \\
\text { Squares }\end{array}$ & Df & $\begin{array}{l}\text { Mean } \\
\text { Square }\end{array}$ & $\mathrm{F}$ & Sig. \\
\hline $\begin{array}{ll}\mathrm{x} & \text { Betwee (Combined) } \\
* & \mathrm{n}\end{array}$ & $\begin{array}{r}3369.95 \\
2\end{array}$ & 18 & 187.220 & 7.291 & .000 \\
\hline
\end{tabular}




\begin{tabular}{|lc|r|r|r|r|r|}
\hline $\mathrm{y}$ Groups Linearity & 2903.88 & 1 & 2903.88 & 113.08 & .000 \\
& 3 & & 3 & 0 & \\
$\begin{array}{l}\text { Deviation } \\
\text { from } \\
\text { Linearity }\end{array}$ & 466.069 & 17 & 27.416 & 1.068 & .409 \\
\hline Within Groups & $\begin{aligned} 1283.99 \\
0\end{aligned}$ & 50 & 25.680 & & \\
\hline Total & 4653.94 & 68 & & & \\
\hline
\end{tabular}

Sumber: Output SPSS

Dari output di atas dapat diketahui bahwa signifikansi pada Linearity adalah sebesar 0,000. Karena signifikansi kurang dari 0,10 maka dapat disimpulkan bahwa antara variabel kualitas pelayanan dan kepuasan penumpang terdapat hubungan yang linear.

\section{Uji Koefisien Korelasi (r)}

Dari output SPSS diperoleh tabel berikut:

\section{Tabel 6}

Hasil Uji Koefisien Korelasi Model Summaryb

\begin{tabular}{|l|c|r|r|r|r|}
\hline Model & $\mathrm{R}$ & $\begin{array}{c}\mathrm{R} \\
\text { Square }\end{array}$ & $\begin{array}{c}\text { Adjusted } \\
\mathrm{R} \text { Square }\end{array}$ & $\begin{array}{c}\text { Std. Error of } \\
\text { the Estimate }\end{array}$ & $\begin{array}{l}\text { Durbin- } \\
\text { Watson }\end{array}$ \\
\hline 1 & $.790^{\mathrm{a}}$ & .624 & .618 & 5.111 & 1.809 \\
\hline
\end{tabular}

a. Predictors: (Constant), y

b. Dependent Variable: s1

Nilai koefisien korelasi (r) adalah sebesar 0,790. Artinya antara variabel kualitas pelayanan $(\mathrm{X})$ dengan kepuasan penumpang $(\mathrm{Y})$ memiliki hubungan yang kuat. Hal ini sesuai dengan pendapat Sugiono dalam buku Dwi Priyatno (2008:54) yang menyatakan bahwa nilai $r$ dalam rentang 0,60-0,799 menunjukkan tingkat hubungan yang kuat.

\section{Uji Koefisien Determinasi}

Dari output SPSS diperoleh tabel berikut:

\section{Tabel 7}

Hasil Uji Koefisien Determinasi Model Summaryb

\begin{tabular}{|l|c|c|c|c|c|}
\hline Model & $\mathrm{R}$ & $\begin{array}{c}\mathrm{R} \\
\text { Squar } \\
\mathrm{e}\end{array}$ & $\begin{array}{c}\text { Adjusted } \\
\text { R Square }\end{array}$ & $\begin{array}{c}\text { Std. Error of the } \\
\text { Estimate }\end{array}$ & $\begin{array}{c}\text { Durbin- } \\
\text { Watson }\end{array}$ \\
\hline 1 & $.790^{\mathrm{a}}$ & .624 & .618 & 5.111 & 1.809 \\
\hline
\end{tabular}

a. Predictors: (Constant), y

b. Dependent Variable: s1

Nilai koefisien determinasi adalah sebesar 0,624. Hal ini menjelaskan bahwa variabel kualitas pelayanan $(\mathrm{X})$ hanya memberikan pengaruh $62,4 \%$ terhadap kepuasan 
penumpang (Y) sedangkan sisanya 37,6\% dipengaruhi oleh variabel lain yang tidak diteliti dalam penelitian ini.

\section{Persamaan Regresi}

Dalam penelitian ini dilakukan perhitungan persamaan regresi linier sederhana untuk mengetahui hubungan fungsional antara variabel kualitas pelayanan (X) dengan kepuasan penumpang (Y) pada PT. ASDP Indonesia Ferry (Persero) Cabang Sibolga.

\section{Tabel 8}

\section{Koefisien Korelasi (r)}

Coefficients $^{\mathbf{a}}$

\begin{tabular}{|c|c|c|c|c|c|}
\hline \multirow[b]{2}{*}{ Model } & \multicolumn{2}{|c|}{$\begin{array}{c}\text { Unstandardized } \\
\text { Coefficients }\end{array}$} & $\begin{array}{l}\text { Standardize } \\
\mathrm{d} \\
\text { Coefficients }\end{array}$ & & \\
\hline & $\mathrm{B}$ & Std. Error & Beta & $\mathrm{t}$ & Sig. \\
\hline $\begin{array}{l}\text { (Constant) } \\
\text { Y }\end{array}$ & $\begin{array}{l}3.514 \\
1.176\end{array}$ & $\begin{array}{r}5.107 \\
.112\end{array}$ & .790 & $\begin{array}{r}4.688 \\
10.544\end{array}$ & $\begin{array}{l}.494 \\
.000\end{array}$ \\
\hline
\end{tabular}

a. Dependent Variable: s1

Sumber: Output SPSS

Bersarkan tabel di atas dapat diketahui bahwa nilai konstanta adalah sebesar 3,514 dan koefisien regresi kualitas pelayanan adalah 1,176 Adapun persamaan regresinya adalah:

\section{Kepuasan Penumpang $=3,514+1,176$ Kualitas Pelayanan}

Dari persamaan di atas dapat disimpulkan bahwa:

a. Konstanta sebesar 3,514 artinya apabila variabel kualitas pelayanan nilainya 0 , maka kepuasan penumpang nilainya 3,514.

b. Koefisien variabel kualitas pelayanan sebesar 1,176 artinya jika variabel kualitas pelayanan meningkat 1 satuan, maka kepuasan penumpang akan mengalami peningkatan sebesar 1,176 satuan.

\section{Uji t}

Uji t digunakan untuk mengetahui apakah variabel kualitas pelayanan (X) berpengaruh signifikan terhadap kepuasan penumpang (Y) pada PT. ASDP Indonesia Ferry (Persero) Cabang Sibolga.

Berdasarkan Tabel 8 di atas dengan melihat dk (derajat kebebasan) $=\mathrm{N}-2$, dimana $\mathrm{N}$ adalah jumlah data dalam penelitian ini $(\mathrm{dk}=69-2=67)$ sehingga $\mathrm{t}_{\text {tabel }}$ dalam penelitian ini adalah sebesar 1,294. Berdasarkan hasil output di atas dapat dilihat bahwa $t_{\text {hitung }}$ untuk variabel kualitas pelayanan sebesar 10,544 sedangkan $t_{\text {tabel }}$ diperoleh sebasar 1,294dalam hal ini maka $t_{\text {hitung }}>t_{\text {tabel }}(10,544>1,294)$ dan tingkat signifikansi yang diperoleh adalah sebesar $0,000<\alpha(0,1)$ maka $\mathrm{H}_{0}$ di tolak dan $\mathrm{H}_{\mathrm{a}}$ diterima. Jadi dapat disimpulkan bahwa dari hasil pengujian parsial (uji t) terdapat pengaruh kualitas pelayanan terhadap kepuasan penumpang pada PT. ASDP Indonesia Ferry Cabang Sibolga.

\section{Pembahasan}


Dari hasil pengolahan data yang dilakukan menunjukkan adanya hubungan yang kuat antara kualitas pelayanan (X) terhadap kepuasan penumpang (Y). Hal ini ditunjukkan oleh nilai $\mathrm{r}$ sebesar 0,790. Hal ini mengindikasikan adanya hubungan kualitas pelayanan (X) terhadap kepuasan penumpang (Y) yang kuat, namun masih banyak lagi faktor lain yang mempengaruhi kepuasan penumpang (Y). Masih banyak faktor lain yang mempengaruhi kepuasan penumpang antara lain: harga, citra, kelengkapan fasilitas, kecepatan pelayanan, dan lainnya.

Kemudian dari uji regresi linier sederhana diperoleh persamaan sebagai berikut:

\section{Kepuasan Penumpang= 3,514 +1,176 Kualitas Pelayanan}

Dari persamaan di atas terlihat bahwa koefisien variabel Kualitas Pelayanan bernilai positif (+). Hal ini menunjukkan adanya hubungan yang positif atau searah antara variabel kualitas pelayanan dengan kepuasan penumpang. Dengan begitu setiap usaha meningkatkan kualitas pelayanan maka akan meningkatkan kepuasan penumpang pada PT. ASDP Indonesia Ferry Cabang Sibolga.

Berdasarkan uji t yang dilakukan hasilnya menunjukkan bahwa kualitas pelayanan berpengaruh terhadap kepuasan penumpang pada PT. ASDP Indonesia Ferry Cabang Sibolga. Hasil penelitian ini menyatakan bahwa meningkatkan kualitas pelayanan dengan baik akan meningkatkan kepuasan penumpang.

Berdasarkan perhitungan koefisien determinasi ( $r$ square) yang dilakukan diperoleh nilai koefisien determinasi sebesar 0,624. Artinya variabel kualitas pelayanan (X) memberikan pengaruh sebesar 62,4\% terhadap kepuasan penumpang (Y). Sumbangan pengaruh ini cukup besar, artinya kualitas pelayanan ini termasuk elemen yang perlu diprioritaskan untuk menjadi bagian dari budaya kerja PT. ASDP Indonesia Ferry Cabang Sibolga. Hal ini penting mengingat di Kota Sibolga masih ada perusahaan jasa angkutan penyeberangan lain yaitu PT. Wira Jaya Lines yang menjadi pesaing bagi PT. ASDP Indonesia Ferry Cabang Sibolga.

Hasil penelitian ini secara umum sejalan dengan teori-teori yang telah dikemukakan banyak pakar manajemen pemasaran dan peneliti-peneliti terdahulu. Dengan kata lain penelitian ini memperkuat teori-teori terdahulu yang menyatakan bahwa kepuasan konsumen akan sangat dipengaruhi oleh kualitas pelayanan yang mereka terima dari perusahaan.

\section{KESIMPULAN}

Dari hasil penelitian yang telah dilakukan disimpulkan bahwa kualitas pelayanan berpengaruh positif terhadap kepuasan penumpang pada PT. ASDP Indonesia Ferry Cabang Sibolga. Besarnya kontribusi variabel kualitas pelayanan terhadap kepuasan penumpang pada PT. ASDP Indonesia Ferry Cabang Sibolga adalah sebesar 62,4\%, sedangkan sisanya $37,6 \%$ dipengaruhi oleh variabel lain yang tidak diteliti dalam penelitian ini.

\section{DAFTAR PUSTAKA}

\section{Al-Qur'an dan Terjemahannya}

Abdurrahman, Herdiana N. (2015), Manajemen Strategi Pemasaran, Bandung: Pustaka Setia.

Adam, Muhammad (2015), Manajemen Pemasaran Jasa, Bandung: CV Alfabeta. Alma, Buchari (2016), Manajemen Pemasaran dan Manajemen Jasa, Bandung: CV 
Alfabeta.

Al Arif, M. Nur Rianto (2010), Dasar-Dasar Pemasaran Bank syariah, Bandung, Alfabeta.

Al-Maraghi, Ahmad Musthafa (1984), Terjemah Tafsir Al-Maraghi, Semarang: Toha Putra.

Hasan, Ali (2008), Marketing, Yogyakarta:Medpres.

Nasution, M. Nur (2005), Manajemen Jasa Terpadu, Bogor: Gahlia Indonesia.

Nursalam (2012), Manajemen Keperawatan, Jakarta: Salemba Medika.

Nurzaman, Kadar (2013), Manajemen Perusahaan, Bandung: Pustaka Setia.

Prihantoro, Rudy (2012), Konsep Pengendalian Mutu, Bandung: PT. Remaja

Rosdakarya

Shihab, M. Quraish (2002), Tafsir Al-Misbah, Jakarta: Lentera Hati.

Sutanto, Herry dan Khaerul Umam (2013), Manajemen Pemasaran Bank Syariah, Bandung: Pustaka Setia

Tjiptono, Fandy (2007), Service Manajemen: Mewujudkan Layanan Prima, Yogyakarta: Andi Ofset. (2005), Service Quality \& Satisfaction, Yogyakarta: CV Andi Offest.

Umar, Husein (2013), Metode Penelitian untuk Skripsi dan Tesis, Edisi Kedua, Jakarta: Rajawali Pers.

Yuniarti, Vinna S. (2015), Perilaku Konsumen, Bandung: Pustaka Setia. 